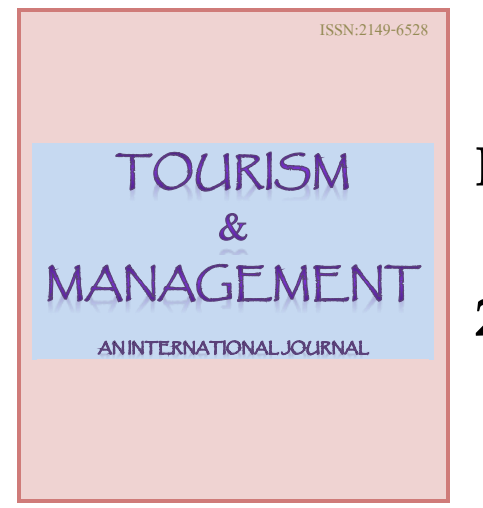

Journal of Tourism and Management Research ISSN 2149-6528

2017 Vol. 2, Issue. 2

\title{
An Empirical Analysis Regarding Family Impact Upon The Business Success: A Case Study in Turkey
}

\begin{abstract}
This study was conducted on the basis of a survey analysis. Survey was distributed among the top management and executives of the family owned firms in Turkey, resulting in 75 responds obtained in total. Although the number of respondents might be perceived as low, the results seem to be reliable and valid, according to the tests of Cronbach's Alpha, Criterion related validity testing, and Structure validity testing. The main results of the research suggest that the most important factors affecting the succession process are family relations, interpersonal relations, and the succession planning process. In addition, gender issues should be addressed in order to identify the possibilities of utilizing more human resources within the company.
\end{abstract}

Keywords: Family-owned firms, Turkey, Succession planning, Gender issues

Tayfun Turgay. Prof.Dr. Rector of Akacan Technical University. Kyrenia/North Cyprus. Email: tavfun.turgay@gmail.com

Sedef Altunbaş Akacan. PhD. Akacan Technical University. Kyrenia/North Cyprus.

e-mail: sedefaltinbas@gmail.com 


\section{Introduction}

Family-owned businesses are defined as firms owned, controlled and operated by the members of one or several families. Historically, most of the large firms, which are currently held publicly, were initially established as family businesses. Many family businesses consist of non-family members as employees, but, specifically in smaller family businesses, the highest positions are usually given to family members. Family-owned businesses make up a very significant portion of all businesses worldwide. They range from very small stores to multinational corporations. More than $80 \%$ of all businesses in the world are family-owned (Peterson-Withorn, 2015). According to Flören (1998, pp.121-122), the most important elements of a family business are directly related to the strategic decision-making and the intention to leave the business to the family. On the other hand, Sharma (2004, p. 4), attributes the significance to the ownership and concentration of management within a family unit. But, the common element in both of these studies is the aim to increase the intraorganizational family based relatedness. Other components that family-owned firms share are as follows (Sharma et al., 2000; Ward, 1997):

- Usually, at least two different generations of the same family govern the firm.

- Family ties become very important in determining the positions within the firm, as well as the executive officials.

- The family name and the firm name grow together, and hence, the success of the firm determines the social status of the family.

- In general, the firm is inherited by the next generation of the family.

- The organizational form of the firm is highly affected by the type of the family and the norms prevailing in the family.

- Although it is possible to have more than one family owning the firm, in general, only one family is influential and has the greatest power in decision making.

According to Yenilmez (2013), four out of five private companies in Turkey are family owned, contributing to $65 \%$ of whole production and employing 7,7 million people, representing $52 \%$ of the total employment. Success in the succession process within the family owned companies may provide them with a significant competitive advantage on the market (Bjuggren and Sund, 2001). This is primarily due to trust and loyalty, and understanding of unique knowledge possessed by family members that provides them with unique capabilities to achieve competitive edge (Ram and Jones, 2002). However, it is generally accepted that only a small fraction, namely 3 in 10 of the family businesses survive to the second generation, while $15 \%$ survive to the third generation (Davis and Harveston, 1998; Ward, 1987). This might be due to the fact that the family businesses often lack the knowledge necessary to plan and control the succession process to the next generation (Kuratko et al., 1993), and it is often neglected in a number of family companies (Bachkaniwala et al., 2001), being one of the rarest event occurring in the business (Fox et al., 1996). Having in mind the importance of the family owned businesses in the Turkish economy, as well as the low rate of success in the management of the transition process, the problem set by this study is to establish the main factors of resistance to the succession process in the FOBs.

Family firms have unique and distinctive characteristics (Chrisman et al., 2005; Moores, 2009). This uniqueness arises from the integration of family and business life, and due to intertwined work and family conditions. Integration of family and business is one of the main starting points in explaining the strategic direction and the decisions made in the family firms (Chrisman et al., 2005). Different frameworks of corporate governance are used to explain the conflicts that arise due to conflicting interests of ownership and control in the firms (Child and Rodrigues, 2003). In Turkey, managers are often perceived as an extension of founders, managing with autocratic leadership style (Marcoulides et al., 1998). The traditional 
companies are characterized by a high degree of centralization, governed by a patriarch, and often lacking any formal rules and procedures (Kozan and Ilter, 1994). This may make the succession process even harder in practice, while researchers largely evaded the investigation of the resistance factors. Businesses in Turkey were investigated regarding the organizational structure and hierarchical relations (Pasa et al., 2001), the planning processes (Iseri and Demirbag, 1999), the nature of decision making (Sozen and Shaw, 2002), and most specifically to the problem of this study, the investigation of dynamics in succession planning within the family owned Turkish companies. Therefore, it seems that the literature on the family firms in Turkey provides no holistic explanation of how the decisions are made in the family owned firms due to complexity of interconnection between the family and the business. Daily and Dollinger (1992), depicted a few reasons why the corporate governance is not the primary concern of the researchers in the field. These include the idea of researchers that the business control lies in the hand of managers and not families; the difficulty of holistic examination of families and management is due to different branches of scientific investigation and belief that families and work spheres exist independently. Therefore, the significance of this study is that it will investigate the area that is largely left unexamined. This study aims to contribute to the knowledge by:

- Developing on the small body of research related to family businesses,

- Investigating the main resistance factors in practice in the Turkish environment, and

- Developing a set of recommendations for business succession processes in Turkey, able to serve as a starting point in gaining succession knowledge of the vast majority of companies in Turkey.

\section{Theoretical Framework and Hypotheses}

\subsection{Family Firms}

As Kepner (1983) argues, family businesses are different from non-family businesses due to overlapping of the business tasks and kinship consideration. This ultimately creates the dilemmas of management of the family ties and managing the work. In order to depict family firms, Tagiuri and Davis (1982), created a 3 Circle Model to illustrate the family firms in the space between management, ownership and family (presented in the Figure below). This model presents the impact of the family component on the ownership and management of the family business (Tagiuri and Davis, 1996), which is non-existent in the non-family businesses.

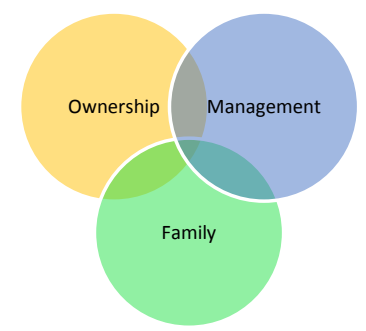

Figure 1 Circle Model by Taigiuri and Davis (1992)

Source: Adapted from Taigiuri and Davis (1992)

\subsection{Family Firms and Succession Issues}

Handler (1994), noted that succession is the process that represents the most important issue of the family firms. It is recognized for the overall survival of the family firms (Ward, 1987). Defined by Handler (1994) as a process of passing the management and control to the next family generation, it was theorized as a key factor in the continuity of a family business. A 
number of authors have discussed this issue and recognized several factors that should support and facilitate the overall transition, and ultimately, reduce the number of firms that cease to exist due to mistakes. These factors that are increasing the overall effectiveness of the transition of control between generations in family businesses will be considered in this segment. Namely, the literature recognizes a few factors that could have a significant effect on the transition process, including development of the transition plan, estate planning, communication and trust between family members, preparation of heirs and creating a robust governance structure.

De Vries (1993) recognized the transition plan as the most important element in a successful family transition. Such plan includes the recognition of the future plans of the company and its targets, the main actions that heirs should conduct in order to achieve these goals and how they should be prepared. Carlock and Ward (2010), argue that the incumbent leaders should identify the potential successors, then select a single leader or a team, and ultimately, support them. This is due to the fact that the generation transition could not be, and should not be, done in a single day. Hence, the planning and preparation for the succession should be considered early on. In addition, this should enable the current generation to monitor the progress of successors and to help them on their way to developing their leadership style, while at the same time benefiting the next generation by providing support and experience from the senior colleagues (Carlock and Ward, 2010).

Morris et al. (1997) recognized that the succession process between the family members in the family firms tends to be more successful and smoother if the relations among the family members are based on loyalty and trust. The family business that is not characterized by mutual trust and effective communication leads to disappearance of the most important quality and competitive advantage of these firms. Therefore, good and healthy communication should be fostered and encouraged among the family members within the firm, reaching the same targets for the business in the future and sharing the same values.

In addition, there might be conflicts over the distribution of profits among family members or across generations that could hinder any change processes in the business (Kozan and Ilter, 1994). Change and institutionalization would set the rules and regulations, and generate an appropriate way of distribution for the family business. This would further prevent possible conflicts and enable a stable plan over time. From the organizational point of view, resistance to change would prevent establishing specific roles and procedures for promotion within the family business. When these are lacking, non-family members might think that their positions would not improve, and hence, they would be less motivated. Furthermore, the non-members might actively try to switch companies as a result, which could lead to a loss of highly-skilled employees by the companies, a concern that exists for $81 \%$ of the Turkish family businesses as opposed to $46 \%$ of family businesses in the world (Tasman-Jones, 2013). Therefore, job divisions should be organized based on objective criteria.

The family members might have disputes about the direction of change and successors in the business (DiMaggio, 1988). Having an institutional structure would help to solve these issues. In particular, if these practices are implemented over a long time, the cost of such disputes significantly declines, which would considerably increase the resources for productive uses. In the family businesses with resistance to change, new ideas are not welcomed (Ribeiro and Scapens, 2006). The family members might prefer the status quo and refrain from trying risky strategies. However, change and institutionalization are required to make innovations and inventions possible in the business, leading to higher performance and flexibility and paving the way for further growth potentials (Perkmann and Spicer, 2007). These factors also increase the ability of the family-owned companies to adapt to market conditions faster. From the point of view of organizational culture, it is very important to 
create an organizational culture that could accept change: Family-owned firms frequently mix family values and business values. However, sometimes a distinction is more useful.

Family-owned firms with members who appreciate business values but lack the perception for sustainable growth, might end up employing family members with low education. Even though this could prove to be successful in the short-run, in the long- run it would cause human capital restrictions (Lawrence and Suddaby, 2006). Moreover, familyowned firms without strict business values tend to utilize more informal methods and trial and error rather than keeping good statistics and reports. Overall, restructuring, institutionalization and change could assist the growth of family businesses.

A number of studies suggest that the equal managerial and professional education does not lead to promotion of women to the higher positions as it does for men (Ogenyi and Victoria, 2004). In the last couple of decades, the overall situation of the female progression improved, however, the executive decisions are usually still held by men (Davy, 2008). The decision to appoint the successor in a family owned firm can be seen as a rational decision, where the founder/incumbent leader is evaluating the potential for success of the future successor. Thus, the obstacles that are perceived to have an influence on women entrepreneurs may be an important factor in such decision. That is, if women with the same traits as men are faced with a higher number of obstacles, the incumbent leader may be more inclined to appoint men, as they will have a higher chance to succeed, other things constant. Therefore, this segment will depict some of the main obstacles that women entrepreneurs face in Turkey.

According to Jennings and Brush (2013), one of the most prominent obstacles that is persistent in the entrepreneurship studies, and that is relevant for women in Turkey is the stereotypical view on the leader role. That is, leaders in organizations are stereotypically seen as masculine, and therefore, the efforts and the results of women entrepreneurs are usually seen less positively. These beliefs of the players on the market are hidden discriminatory practices that inhibit the entrepreneurship activities of women. However, these hidden discriminatory practices are not isolated. According to Karatas-Ozkan et al. (2010), Turkish women entrepreneurs might be faced with open (overt) and hidden (covert) discrimination in business life. This is exemplified by the significant wage gap as society perceived female entrepreneurship and employment as less valuable.

Karatas-Ozkan et al. (2010), noted that because of the problem of stereotyping, women are nearly invisible, as businessmen are more inclined to trust and deal with men than with women. Therefore, an additional problem that might be crucial in family businesses is that women are often faced with such invisibility (Hollander and Bukowitz, 1990). Male incumbent leaders, as well as potential successors, tend to be doubtful of women's (e.g. daughters) competences, imposing on them an additional challenge compared to their male counterparts (Barnes and Kaftan, 1990). However, these challenges are not coming only from the incumbent leader and the potential male successors, but also the wider recognition of women leadership is questioned by the employees and colleagues (Barnes, 1988). In addition to this, women are faced with the additional problem of finding mentors and establishing mentor relationships. Karatas-Ozkan et al. (2011) noted that women in business life are faced with a difficulty in finding mentors who will provide advice for their business career. As such, networks of women within family businesses, as argued by Lyman (1988), are possibly even smaller than networks of women in non-family businesses. Another group of studies identified that the financial support and its acquiring may be a significant impediment for women entrepreneurs. Different studies identified that women are faced with substantial difficulties in obtaining loans in Turkey (e.g. Ozdemir, 2010; Ufuk and Ozgen, 2001). Moreover, Ozar (2007) identified that the formal ways of acquiring loans, such as bank loans, are less prominent among female entrepreneurs, especially in the initial stages of their business life, and they are forced to start their business from their own capital or personal 
borrowings from the family and friends. Ozar (2007) identified that some of the problems of women entrepreneurs in the later stages of their business are debt payments, lack of involvement with the male business colleagues, and the resulting low demand, the obtaining of additional lines of credit, and other.

At last, this section will note the conflict of the business and the domestic life, and the resulting stress and anxiety of women as their obstacle for engaging in higher management positions. The studies of Ufuk and Ozgen (2001), and Koyuncu et al., (2012), identified that women in Turkey, regardless of whether they are employees, managers or entrepreneurs, experience significant work-life and work-family conflict. Parasuraman et al. (1996), noted that this could result in higher stress for women, which as an effect results in a self-fulfilling prophesy, decreasing the overall performance of women at work (Jennings and McDougald, 2007).

\subsection{Gaps in the Research of Succession Process in FOBs in Turkey}

The succession process is largely neglected by the empirical research. This is due to the fact that it is one of the rarest effects occurring in the life of the business (Fox et al, 1996). However, while there are studies related to succession in developed countries (e.g. BretonMiller, Miller and Steier, 2004; Sonfield and Lussier, 2004; Whatley, 2011), this area of research seems not to be covered by the empirical studies for some of the developing countries, including Turkey. In addition, the gender issues in succession process were generally not considered.

Based on the literature above, the following research hypotheses were proposed together with the study model (see figure 2).

Hypothesis 1: Succession planning has significant positive effect on the succession process in FOBs in Turkey.

Hypothesis 2: Gender Issues have a significant positive effect on the succession process in FOBs in Turkey.

Hypothesis 3: Interpersonal relations have a significant positive effect on the succession process in FOBs in Turkey.

Hypothesis 4: Family relations have a significant positive effect on the succession process in FOBs in Turkey.

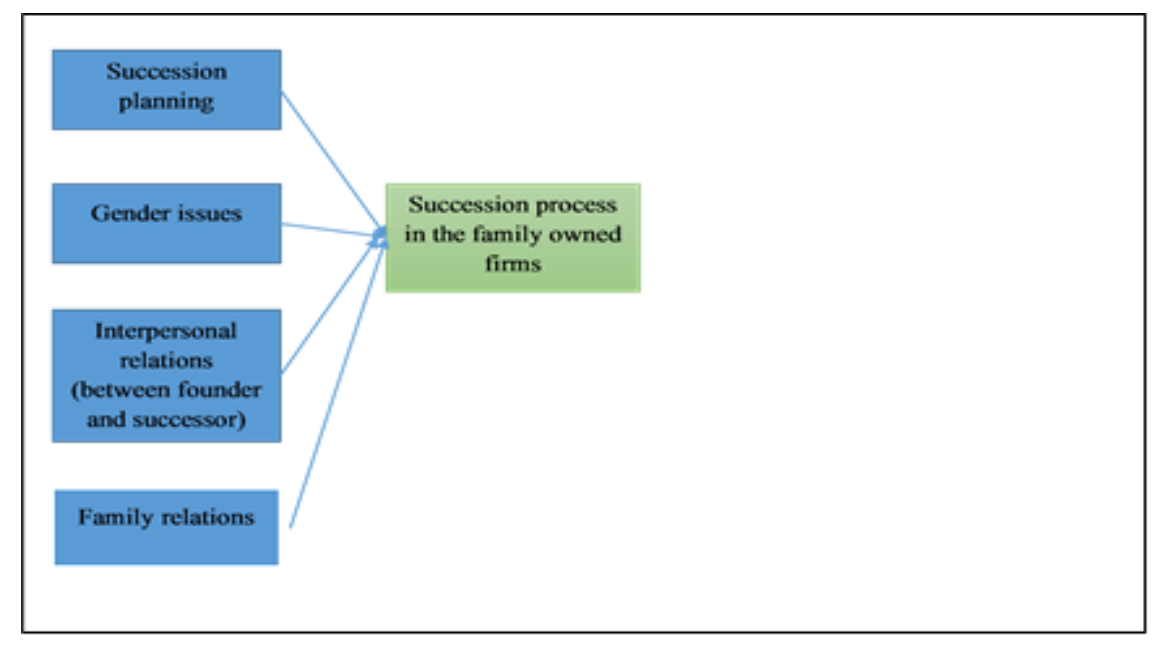

Figure 2. The proposed Model 


\section{Methodology}

\subsection{Research Design}

This study was based on the survey analysis. In such administrated survey, the nonprobability sampling was used, where not all individuals have equal chance to be a part of being surveyed. That is three basic rules for the sampling were used (i) only top management were surveyed, (ii) they have to be from family owned companies and (iii) company need to be from Turkey. The characteristics of such strategy are that it is more focused and usually less time consuming. However, as it is focused, and not exhaustive, it will not reflect the beliefs of the entire population, but only the beliefs on the issues raised in the study of the top management in Turkish family owned companies. Also, the survey was distributed through three main channels, in person, through emails and through additional online survey methods.

\subsection{Instrumentation}

The results of the survey will be reported in the quantitative form, where these quantitative values will be used to measure the intensity of the specific item measured. Such quantification would allow the research to compare and evaluate the relative importance of the different items. That is, the researcher asked from responders to rate the intensity of specific statements on Five point Likert scale, where 1 is strongly disagree, 2 disagree, 3 nor agree nor disagree, 4 agree and 5 strongly agree.

\subsection{Procedure}

The results from the survey were analysed on the basis of one sample $t$ test. Having in mind that the questions and statements were asked to be rated on the scale 1-least agree to 5-most agree, and that 3 is the value of "neither agree nor disagree", the test is performed to identify if the values are significantly different from 3 . The results obtained in such procedure were judged on the basis of the t-statistics and subsequently explained on the basis of the range of difference to neutral value (3). If they are significantly different from 3, at 5\% significance level, the can be either negative influencers or positive influencers, based on the mean difference. This procedure will be independently done through all separate possible factors of the succession planning identified in the literature review and constructed for this model. The analysis and the subsequent interpretation are done on the rules in the following Table 1. Namely, in the case when the mean value is higher than 4, the item is considered to be highly important (most of the respondents are in the group of "agree" and "strongly agree" group). The items with the mean value of between 3 and 4, but significant, are interested as moderately important. Alternatively, the items with the mean value between 3 and 2 are considered to be moderately negative factors, while factors below 2 are considered strongly negative factors.

Table 1. Rules for interpretation of results.

\begin{tabular}{|l|l|}
\hline Value of mean (and resulting mean difference) & Interpretation \\
\hline Above 4 (and above 1) & Strongly important \\
\hline $\begin{array}{l}\text { Between 3 and 4 (and less than 1) but statistically } \\
\text { significant }\end{array}$ & Moderately important \\
\hline 3 (and mean difference 0) & Insignificant \\
\hline Between 2 and 3 (between 0 and -1) & Moderately negative \\
\hline Between 1 and 2 (between -1 and -2) & Strongly negative \\
\hline
\end{tabular}

In addition to this, the following discussion will adopt some basic notations. Namely, the "factors" in this study refers to the factors that have the potential to influence succession 
process (including founder's influence, successor's influence, family relations, interpersonal relations, succession planning, organizational factors, environmental factors and gender issues). On the other hand, the "item" is used to describe the set of items or statements that are used to measure such factors. That is, each factor has a number of items, and while some of the items may be insignificant, it does not necessarily mean that the overall factor will be insignificant.

\section{Results}

\subsection{Demographic Characteristics of Respondents}

In this research 75 responds were collected from the top managers in the family firms in Turkey. Main demographic characteristics of the sample are presented in the table 2 below.

Table 2. Demographic characteristics of the responders.

\begin{tabular}{|c|c|c|c|}
\hline & & Frequency & Percent \\
\hline Gender & $\begin{array}{l}\text { Female } \\
\text { Male }\end{array}$ & $\begin{array}{l}6 \\
69\end{array}$ & $\begin{array}{l}8 \\
92\end{array}$ \\
\hline Age & $\begin{array}{l}18-30 \\
30-40 \\
40 \text {-above }\end{array}$ & $\begin{array}{l}13 \\
21 \\
41\end{array}$ & $\begin{array}{l}17.3 \\
28 \\
54.7 \\
\end{array}$ \\
\hline Education & $\begin{array}{l}\text { High School } \\
\text { University } \\
\text { Post-graduate }\end{array}$ & $\begin{array}{l}12 \\
46 \\
17 \\
\end{array}$ & $\begin{array}{l}16 \\
61.33 \\
22.67 \\
\end{array}$ \\
\hline Work experience & $\begin{array}{l}0-5 \\
5-10 \\
10-15 \\
15 \text {-above } \\
\end{array}$ & $\begin{array}{l}16 \\
23 \\
25 \\
11 \\
\end{array}$ & $\begin{array}{l}21.3 \\
30.7 \\
33.3 \\
14.7\end{array}$ \\
\hline $\begin{array}{l}\text { Work for other } \\
\text { company }\end{array}$ & $\begin{array}{l}\text { No } \\
\text { Yes }\end{array}$ & $\begin{array}{l}41 \\
34\end{array}$ & $\begin{array}{l}54.7 \\
45.3\end{array}$ \\
\hline Relation to founder & $\begin{array}{l}\text { Father } \\
\text { Founder } \\
\text { Grandfather } \\
\text { Other }\end{array}$ & $\begin{array}{l}17 \\
11 \\
11 \\
36\end{array}$ & $\begin{array}{l}22.7 \\
14.7 \\
14.7 \\
48\end{array}$ \\
\hline Family member & $\begin{array}{l}\text { No } \\
\text { Yes }\end{array}$ & $\begin{array}{l}13 \\
62\end{array}$ & $\begin{array}{l}17.3 \\
82.7\end{array}$ \\
\hline $\begin{array}{l}\text { Generation of the } \\
\text { firm }\end{array}$ & $\begin{array}{l}1 \mathrm{st} \\
2 \mathrm{nd} \\
3 \mathrm{rd}\end{array}$ & $\begin{array}{l}51 \\
15 \\
9\end{array}$ & $\begin{array}{l}68 \\
20 \\
12\end{array}$ \\
\hline $\begin{array}{l}\text { Number of } \\
\text { employees }\end{array}$ & $\begin{array}{l}0-10 \\
11-50 \\
51-\text { above }\end{array}$ & $\begin{array}{l}23 \\
39 \\
13\end{array}$ & $\begin{array}{l}30.7 \\
52 \\
17.3\end{array}$ \\
\hline $\begin{array}{l}\text { CEO family } \\
\text { member }\end{array}$ & $\begin{array}{l}\text { No } \\
\text { Yes }\end{array}$ & $\begin{array}{l}5 \\
70\end{array}$ & $\begin{array}{l}6.7 \\
93.3\end{array}$ \\
\hline CEO age & $\begin{array}{l}18-30 \\
30-40\end{array}$ & $\begin{array}{l}9 \\
25\end{array}$ & $\begin{array}{l}12 \\
33.3\end{array}$ \\
\hline
\end{tabular}




\begin{tabular}{|l|l|l|l|}
\hline $\begin{array}{l}40-\text { above } \\
\text { Total }\end{array}$ & 41 & 54.7 \\
75 & 100 \\
\hline
\end{tabular}

\subsection{Reliability and Validity Test}

The reliability of the research instruments, as a measure of the consistency of responds were measured (Kimberlin and Winterstein, 2008). If the instruments are reliable, respondents with similar backgrounds should provide similar answers and the variability should be due to the real differences in the respondents, and not differences in the comprehension and understanding of the questions. Reliability was tested based on Cronbach's Alpha. It seems that the more accepted threshold for reliability of instruments is 0.7 , as suggested by Cortina (1993) and Spiliotopoulou (2009). As it can be seen from table 3 below, all the results are above both thresholds, and as such, the instruments may be considered as reliable.

Table 3. Cronbach's Alpha

\begin{tabular}{|l|l|l|}
\hline & $\begin{array}{l}\text { No of } \\
\text { items }\end{array}$ & Cronbach's Alpha \\
\hline Interpersonal relations & 7 & 0.742 \\
\hline Family relations & 5 & 0.762 \\
\hline Succession planning & 5 & 0.743 \\
\hline Gender issues & 8 & 0.881 \\
\hline
\end{tabular}

In addition to this, statistical tests for validity of the questionnaire were conducted. The Structure validity test (Pearson test) which is "used to test the validity of the questionnaire structure by testing the validity of each field and the validity of the whole questionnaire" was employed for this purpose (Elnagar, 2016). It is used to test the structural validity of the entire questionnaire, by testing the correlation of each field against the entire questionnaire. The results suggested that structure validity with a p-value of under 0.01 is achieved at $1 \%$ statistical significance level. Also criterion related validity testing was employed. This test is used to measure the correlation of coefficients between each item in the field. The correlation values, with the p-values that are less than 0.01 suggest that this correlation is significant at $1 \%$ statistical significance level in all the cases. Therefore, this test suggests that the study has validity.

\subsection{Frequency for Measures}

Table 4 below demonstrates the mean scores based on the respondents' answers ranges between " 1 " strongly disagree and " 5 " strongly agree.

Table 4. Mean scores for measures.

\begin{tabular}{|c|c|c|c|c|c|}
\hline Measures & 1 & 2 & 3 & 4 & 5 \\
\hline $\begin{array}{l}\text { Interpersonal } \\
\text { relations }\end{array}$ & $\begin{array}{l}\text { strongly } \\
\text { disagree }\end{array}$ & disagree & $\begin{array}{c}\text { nor disagree } \\
\text { nor agree }\end{array}$ & agree & $\begin{array}{c}\text { strongly } \\
\text { agree }\end{array}$ \\
\hline IR1 & 0 & 2 & 10 & 32 & 31 \\
\hline IR2 & 0 & 6 & 12 & 27 & 30 \\
\hline IR3 & 3 & 9 & 7 & 19 & 37 \\
\hline IR4 & 4 & 9 & 9 & 20 & 33 \\
\hline
\end{tabular}




\begin{tabular}{|l|r|r|r|r|r|} 
IR5 & 4 & 8 & 15 & 23 & 25 \\
\hline IR6 & 1 & 7 & 18 & 27 & 22 \\
\hline IR7 & 0 & 8 & 9 & 23 & 35 \\
\hline $\begin{array}{l}\text { Family } \\
\text { relations }\end{array}$ & & & & & \\
\hline FR1 & 0 & 0 & 24 & 28 & 23 \\
\hline FR2 & 0 & 4 & 25 & 25 & 21 \\
\hline FR3 & 0 & 0 & 25 & 27 & 23 \\
\hline FR4 & 0 & 0 & 21 & 25 & 29 \\
\hline FR5 & 0 & 0 & 8 & 46 & 21 \\
\hline Succession & & & & & \\
planning & 0 & 0 & 6 & 46 & 23 \\
\hline SP1 & 0 & 0 & 9 & 40 & 26 \\
\hline SP2 & 0 & 0 & 21 & 38 & 16 \\
\hline SP3 & 0 & 0 & 6 & 51 & 18 \\
\hline SP4 & 8 & 24 & 21 & 18 & 4 \\
\hline SP5 & & & & & 27 \\
\hline Gender issues & 1 & 5 & 12 & 30 & 23 \\
\hline GI1 & 4 & 4 & 16 & 28 & 23 \\
\hline GI2 & 4 & 7 & 22 & 32 & 10 \\
\hline GI3 & 5 & 6 & 21 & 28 & 15 \\
\hline GI4 & 20 & 23 & 17 & 8 & 16 \\
\hline GI5 & 5 & 7 & 20 & 23 & 16 \\
\hline GI6 & & 4 & 21 & 31 & 16 \\
\hline GI7 & & & & & \\
\hline GI8 & & & & & \\
\hline
\end{tabular}

\subsection{Findings}

In this segment, the summary of all the results obtained will be depicted. The results of the factors investigated will be summarized in the following four groups: group of strongly positive factors (with the mean difference higher than 1), moderately positive factors (with the mean difference up to 1, but statistically significant), not important factors (mean difference is not statistically significant), and "conditionally negative" factors (as explained earlier) with negative, but significant mean difference. Therefore, out of the 25 items that were used, 10 were identified to have a strong positive influence and 13 to have moderate positive influence on the succession process. Only one of them was found to be insignificant and the remaining one to have a negative influence on the succession process. It seems that the highest number of positive factors is coming from the group of interpersonal relations factors, even 4 of them. Moreover, succession planning also seems to be highly valued by the respondents, having in mind that 3 of the total strong influencers are coming from this segment. Also, family relations are seen as important, having in mind that 2 of the factors have a strong influence, while 3 have a moderate positive influence on the succession process. In addition to this, we were interested in the relative importance of each of the factors used. That is, which of these factors are perceived by the responders as the most important, and which as the least important. For that purpose, the average value of the absolute mean difference for each factor was calculated. If the factor is insignificant, statistically it cannot be perceived as different from 0 , therefore, such factors were assigned with the null value. 
It seems that such analysis provides a clearer picture on the importance of each factor. According to the results, the most important factor for succession, perceived by the top managers of family businesses in Turkey, is in fact the factor of family relations. This factor just slightly "outperformed" the second rated factor, interpersonal relations. This factor was primarily designed to measure the relations of successor and founders (or incumbent leader). Third rated factor, only slightly below all the above, is succession planning. Namely, although this factor is expected to be important, and as such, perceived to be important by the managers, one item that is used to measure it was found to be insignificant. Therefore, the overall importance of this factor may be even higher if only the average of the important items was calculated. That is, while the "un-important" factor was given the value of 0 , if it is not calculated at all (un-adjusted mean difference), this factor is seen as the most important factor for managers in Turkey. This might suggest a few things. Namely, it might be that the factor that is un-important is seen as such due to different cultural and behavioural values of managers in Turkey, or it might mean that certain items seen by the theory are either not important or out-dated.

Although gender issues are considered as important in all their items, they are not seen to be of high importance as much as the previous factors. Namely, the mean difference of the joint value of the gender factor is lower than in most of the other factors. However, it has to be noted that this factor is constituted of certain claims on the leadership potential of males and females, and females (as previously presented) generally disagreed with these statements. As a result, it is quite possible that the value of the mean difference for the entire sample significantly decreased.

\section{Conclusion, Implications, and Limitations}

The main results of the research suggest that the most important factors affecting the succession process are family relations, interpersonal relations, and the succession planning process. In addition, gender issues should be addressed in order to identify the possibilities of utilizing more human resources within the company. Based on the results of this research, there are a few implications for practitioners and family companies aspiring for succession. Namely, among the two most important factors that are seen by the managers in the family owned companies in Turkey are family and interpersonal relations. The succession process should be evaluated and planned within the broader context of the influence and acceptance of the family. This seems to accent the issue of "familiness" and its importance for the family firms in Turkey. Together with these, the succession planning process is seen as a highly important factor that depicts the necessity that the succession planning should be drafted by the joint effort of the founder and the successor. With no trust, mentoring of potential heirs, encouragement and support by the founders, but also by the other members of the family, the overall succession process may be a daunting task, and destined for failure.

It is also recognized that gender issues, or the gender of the future heir may have an effect on the succession process. Therefore, the practitioners and managers may work towards empowering women and communicating their value for the company through the firm. This is not only the case for ethical issues and approach to women. This is due to the fact that the stereotypes that, as suggested, exist in the family firms in Turkey, may result in decreasing the potential pool of candidates for succession. Namely, there is a possibility that the best candidate for succession is, in fact, a woman, while the stereotypes result in certain bias towards the male candidates for succession. The overall empowerment of women in the organization would possibly lead to the best person being chosen for the best job, increasing the competitive advantage of the firm, its profitability and success on the market. In the competitive market, and guided by the principles of the profit seeking, family owned companies might therefore benefit if certain practices guided towards establishing gender 
equality are implemented. This does not only refer to change of beliefs and attitudes in the companies, but also to providing effective mentorship and practices oriented on establishing efficient work-life balance for women in the company. The study lacked an in-depth qualitative dimension. Future studies could use in-depth interviews as an alternative approach to provide richer insights into the antecedents and outcomes.

\section{References}

Bachkaniwala, D., Wright, M., \& Ram, M. (2001). Succession in South Asian family businesses in the UK. International Small Business Journal, 19(4), 15-27.

Bjuggren, P. O., \& Sund, L. G. (2001). Strategic Decision Making in Intergenerational Successions of Small-and Medium-Size Family-Owned Businesses. Family Business Review, 14(1), 11-24.

Breton-Miller, I. L., Miller, D., \& Steier, L. P. (2004). Toward an integrative model of effective FOB succession. Entrepreneurship Theory and Practice, 28(4), 305-328.

Carlock, R.S. and Ward, J.L., (2010). When Family Businesses are Best: The Parallel Planning Process for Family Harmony and Business Success. Hampshire: Palgrave MacMillan.

Child, J. \& Rodrigues, S., (2003). Co-evolution in an institutionalized environment. Journal of Management Studies, 40(8), 2137-2162.

Chrisman, J.J., Chua, J. H., and Steier, L.P. (2005) Important attributes of successors in family business: An explanatory study. Family Business Review, 11(1), 19-34.

Cortina, J. M. (1993). What is coefficient alpha? An examination of theory and applications. Journal of applied psychology, 78(1), 98.

Daily, C. M. \& Dollinger, M. J. (1992). An empirical examination of ownership structure in family and professionally managed firms. Family Business Review, 5(2), 117-136.

Davis, P. S., \& Harveston, P. D. (1998). The influence of family on the family business succession process: A multi-generational perspective. Entrepreneurship Theory and Practice, 22, 31-54.

Davy, K. M. (2008). Women's account of organizational politics as a gendering process. Gender Work and Organization, 15(6), 650-671.

De Vries, M. F. K. (1993). The dynamics of family controlled firms: The good and the bad news. Organizational Dynamics, 21(3), 59-71.

DiMaggio, P. J. (1988). Interest and agency in institutional theory. Institutional Patterns And Organizations: Culture And Environment, 1, 3-22.

Elnagar, B. M. (2016). Factors Affect Students Achievement in Their Examinations. European Scientific Journal, 12(1).

Flören, R. H. (1998). The significance of family business in the Netherlands. Family Business Review, 11(2), 121-134.

Fox, M., Nilakant, V., \& Hamilton, R. T. (1996). Managing succession in family-owned businesses. International Small Business Journal, 15(1), 15-25.

Handler, W. C. (1994). Succession in family business: A review of the research. Family Business Review, 7(2), 133-157.

Hollander BS and Bukowitz WR (1990). Women, family culture, and family business. Family Business Review, 3(2), 139-51.

Iseri, A and Demirbag, M. (1999). Overcoming Stereotyping: Beyond Cultural Approach. Middle East Business Review, 3(1), 1-21. 
Jennings, J. E., \& Brush, C. G. (2013). Research on women entrepreneurs: challenges to (and from) the broader entrepreneurship literature? Academy of Management Annals, 7(1), 663-715.

Jennings, J. E., \& McDougald, M. S. (2007). Work-family interface experiences and coping strategies: Implications for entrepreneurship research and practice. Academy of Management Review, 32(3), 747-760.

Karataş-Özkan, M., Erdoğan, A., \& Nicolopoulou, K. (2011). Women in Turkish family businesses: Drivers, contributions and challenges. International Journal of Cross Cultural Management, 11(2), 203-219.

Karatas-Ozkan, M., Inal, G. and Ozbilgin, M. (2010). Turkey. In Fielden, S. and Davidson, M. (Eds), International Handbook of Successful Women Entrepreneurs, Edward Elgar Press, Cheltenham and New York, NY, pp. 175-188.

Kepner, E. (1983). The family and the firm: a coevolutionary perspective, Organisational Dynamics, 12 (Summer), 57-70.

Kimberlin, C. L., \& Winterstein, A. G. (2008). Validity and reliability of measurement instruments used in research. Am J Health Syst Pharm, 65(23), pp. 2276-84.

Koyuncu, M., Burke, R. J., \& Wolpin, J. (2012). Work-family conflict, satisfactions and psychological well-being among women managers and professionals in Turkey. Gender in Management: An International Journal, 27(3), 202-213.

Kozan, M. K., \& Ilter, S. S. (1994). Third party roles played by Turkish managers in subordinates' conflicts. Journal of Organizational Behavior, 15(5), 453-466.

Kuratko, D. F. (1993). Family business succession in Korean and US firms. Journal of Small Business Management, 31(2), 132.

Lawrence, T. B., \& Suddaby, R. (2006). 1.6 institutions and institutional work. In: The SAGE Handbook of Organization Studies, London: Sage, pp. 215-254

Lyman, A. R. (1988). Life in the family cycle. Family Business Review 1(4), 383-98.

Marcoulides, G. A., Yavas, B. F., Bilgin, Z., \& Gibson, C. B. (1998). Reconciling culturalist and rationalist approaches: leadership in the United States and Turkey. Thunderbird International Business Review, 40(6), 563-583.

Moores, K. (2009). Paradigms and theory building in the domain of business families. Family Business Review, 22, 167-180.

Morris, M. H, Williams, R. O., Allen, J. A., Avilla, R. A. (1997). Correlates of success in family business. Journal of Business Venturing, 12(5), 385-401.

Ogenyi, O., \& Victoria, O. (2004). A Qualitative evaluation of women as managers in the Nigerian civil service. The International Journal of Public Sector Management, 17(40), 360-373.

Ozar, S. (2007). Women entrepreneurs in Turkey: obstacles, potentials and future prospects. Gender Clearing House Site, The Center of Arab Woman for Training and Research (CAWTAR).

Ozdemir, A. A. (2010). Motivation factors of potential entrepreneurs and a research study in Eskisehir. Ege Akademik Bakis, 10(1), 117-139.

Parasuraman, S., Purohit, Y. S., Godshalk, V. M., \& Beutell, N. J. (1996). Work and family variables, entrepreneurial career success, and psychological well-being. Journal of Vocational Behavior, 48(3), 275-300.

Pasa, S., Kabasakal, H., \& Bodur, M. (2001). Society, organisations, and leadership in Turkey. Applied Psychology, 50(4), 559-589.

Perkmann, M., \& Spicer, A. (2007). Healing the scars of history': Projects, skills and field strategies in institutional entrepreneurship. Organization Studies, 28(7), 1101-1122.

Peterson-Withorn, C. (2015). New Report Reveals The 500 Largest Family-Owned Companies In The World. Available at: 
https://www.forbes.com/sites/chasewithorn/2015/04/20/new-report-reveals-the-500largest-family-owned-companies-in-the-world/\#327217e13602 Accessed on [01 March 2017].

Ram, M., \& Jones, T. (2002). Exploring the Connection: Ethnic Minority Businesses and the Family Enterprise. In, Understanding the Small Family Business, ed. DE Fletcher.

Ribeiro, J. A., \& Scapens, R. W. (2006). Institutional theories in management accounting change: contributions, issues and paths for development. Qualitative Research in Accounting \& Management, 3(2), 94-111.

Sharma, P. (2004). An overview of the field of family business studies: Current status and directions for the future. Family Business Review, 17(1), 1-36.

Sharma, P., Chua, J. H., \& Chrisman, J. J. (2000). Perceptions about the extent of succession planning in Canadian family firms. Canadian Journal of Administrative Sciences/Revue Canadienne des Sciences de l'Administration, 17(3), 233-244.

Sonfield, M. C., \& Lussier, R. N. (2004). First-, second-, and third-generation family firms: a comparison. Family Business Review, 17(3), 189-202.

Sozen, S., \& Shaw, I. (2002). The international applicability of "new" public management: lessons from Turkey. International Journal of Public Sector Management, 15(6), 475486.

Spiliotopoulou, G. (2009). Reliability reconsidered: Cronbach's alpha and paediatric assessment in occupational therapy. Australian Occupational Therapy Journal, 56(3), 150-155.

Tagiuri, R., \& Davis, J. (1996). Bivalent attributes of the family firm. Family Business Review, 9(2), 199-208.

Tagiuri, R., \& Davis, J. A. (1982). The advantages and disadvantages of the family business. Research paper.

Tasman-Jones, J. (2013). Infographic: Turkish Family Businesses. Available at: http://www.campdenfb.com/article/infographic-turkish-family-businesses Accessed on [15 January 2017].

Ufuk, H., \& Özgen, Ö. (2001). Interaction between the business and family lives of women entrepreneurs in Turkey. Journal of Business Ethics, 31(2), 95-106

Ward, J. L. (1987). Keeping the family business healthy. 1st ed. San Francisco California: Jossey-Bass.

Ward, J. L. (1997). Growing the family business: Special challenges and best practices. Family Business Review, 10(4), 323-337.

Whatley, L. (2011). A new model for family owned business succession. Organization Development Journal, 29(4), 21-32.

Yenilmez, M.I. (2013). History, development and characteristics of family-owned businesses in Turkey. Available at: http://www.kas.de/wf/doc/kas 37297-1522-230.pdf?140408094729 Accessed on [05 May 2017]. 